EESTI NSV TEADUSTE AKADEEMIA TOIMETISED. XVIII KÖDE KEEMIA * GEOLOOGIA. 1969, NR. 3

ИЗВЕСТИЯ АКАДЕМИИ НАУК ЭСТОНСКОИ ССР. ТОМ ХVIII ХИМИЯ * ГЕОЛОГИЯ. 1969, № 3

Х. ВИИДННГ, Э. ЛЫОКЕНЕ

\title{
СРЕДНЕВАЛДАЙСКИЕ МЕЖСТАДИАЛЬНЫЕ ОТЛОЖЕНИЯ В ПЭЭДУ (ЮГО-ВОСТОЧНАЯ ЭСТОНИЯ)
}

Ход отступания ледникового покрова в верхневалдайское время от границы его максимального распространения до полного стаивания льда в Скандинавском центре оледенения довольно хорошо изучен. Иногда он маркируется в рельефе четко выраженными краевыми образованиями, а в разрезах - находками межстадиальных огпожений, возраст которых в некоторых случаях точно установлен радиоуглеродным методом (Серебрянный, Раукас, 1966 и др.). Гораздо меньше имеется данных о более древних межстадиалах валдайского времени. Соответствующие последним отложения в основном снесены вновь наступающим ледником или же погребены под более молодыми ледниковыми отложениями.

Одним из известных местонахбждений более древних межстадиальных отложений последнего, валдайского, оледенения в Эстонии является местонахождение Карукюла. Межморенные органогенные осадки Карукюла, согласно интерпретации К. Орвику и Р. Пиррус (1965), можно сопоставить с межстадиальными отложениями Брёрупа (возраст около 59000 лег) в Западной Европе. Более поздними радиоуглеродными датировками возраст органического материала из Карукюла определен примерно в 48100 лет (Пуннинг и др., 1967а), т. е. он немного моложе отложений брёрупского межстадиала.

В данном сообщении приводится предварительное описание еще одного местонахождения межстадиальных отложений, по-видимому, одновозрастных с карукюласкими. Это местонахождение, расположенноє в Юго-Восточной Эстонии, представляет несомненный интерес для уточнения стратиграфии верхнего плейстоцена в Эстонии. Об интересной находке погребенного торфа в разрезе колодца в Пээду авторам настоящей статьи сообщил в 1964 г. преподаватель Тартуского государственного университета Г. Дементьев. Слой торфа с крупными остатками древесины (пня сосны) был обнаружен там при заложении колодца под мореной, на глубине 7 м. При ознакомлении с разрезом колодца общей глубиной $22 \mu$ были документированы четвертичные отложения и отобраны образцы из трех различных горизонтов морены, а также из торфа и встречающейся в нем древесины.

Отмеченный выше колодец находится в Юго-Восточной Эстонии, в $25 \kappa м$ к югу от Тарту, в южной части дачного района Пээду. Окружающая местность представляет собой волнистую моренную равнину, прорезанную здесь долиной р. Эльва. Местонахождение межстадиальных отложений расположено в 120 м от левого склона долины.

В стенке колодца обнажились следующие отложения:

200 см морена красновато-бурая, с галькой и валунами известняков и кристаллических пород. (обр. 1. Верхние 50 cм морены выветрены под влиянием почвообразующих процессов). 
80 см морена буровато-серая, песчаная, с гравием и галькой известняков и кристаллических пород. Подошва слоя более песчаная и богата гравием.

150 cм морена буровато-серая, глинистая, с галькой известняков и кристаллических пород.

220 c.м морена серая, глинистая, плотная (обр. 2). Переходы между разновидностями буровато-серых и серой морен более или менее постепенные.

50 см песок от мелко- до среднезернистого, желтовато-бурый, косослоистый.

35 см торф коричневато-черный, высокой степени разложения, с остатками сосновой древесины и сосновых шишек. На поверхностях наслоения иногда наблюдается присыпка тонкозернистого песка. Мощность слоя торфа в разрезе колодца 2535 см. Нижняя граница торфа нечеткая, переходная.

60 см песок мелкозернистый, буровато-серый, с линзовидными гнездами серой глины и торфа около верхней границы слоя. Продолговатые линзочки торфа расположены по косым слойкам.

$80 \mathrm{~cm}$ песок средне- и крупнозернистый, желтовато-бурого, в нижней части серого цвета. Местами в песке наблюдаются гнезда с интенсивной пигментацией гидроокислами железа.

30 см морена серая, гравийная, с галькой известняков, плотная, среднесцементированная (обр. 3).

$1250+$ - мм девонский песчаник мелкозернистый, красновато-бурый, косослоистый, с мелкими прослоями алевролитов и глин.

Типичная для Южной Эстонии красновато-бурая морена широко распространена на моренных равнинах окрестностей Пээду. Краснобурая морена, залегающая непосредственно на песчаниках девона, обнажается местами на мощность $2-3$ м на склонах долины Эльва, недалеко от описанного местонахождения. Поэтому можно предположить, что на месте описанного разреза существует неглубокая погребенная долина, врезанная в песчаники арукюласких слоев среднего девона. В пользу такого предположения говорят как текстурные особенности песков, подстилающих торф, так и обильное присутствие песчинок в торфе. Последний, по-видимому, представляет собой образование поймы, временно затопленной половодьям. На автохтонность слоя торфа указывает отчетливая горизонтальная слоистость, а также находка в нем довольно крупных остатков древесины. В то же время гнезда и катуны глин и линзы торфа в подстилающих аллювиальных песках принесены сюда, вероятно, из болотных отложений, распространенных в районах верховья реки. Покрывающие торф косослоистые пески являются опять-таки типичными аллювиальными песками. Вполне возможнс, что верхняя часть торфа эродирована.

Органогенные отложения Пээду, согласно предварительным данным Э. Лийвранд, содержат пыльцу ольхи (около $50 \%$ ), ели, сосны и пихты, а из широколиственных - зерна граба и вяза (Пуннинг и др., 1967б). Такой состав пыльцы имеет некоторое сходство с составом споровопыльцевых комплексов, полученных К. Орвику и Р. Пиррус (1965) из отложений Карукюла.

Абсолютный возраст этих отложений определен по древесине сосны, встреченной в торфе, в $39180 \pm 1960$ лет (ТА-136). Определение выполнено Я.-М. Пуннингом в лаборатории геобиохимии Института зоологии и ботаники АН ЭССР в 1967 году (Пуннинг и др., 1967а). По образцу торфа, отобранному с того же местонахождения К. Каяком, получен значительно меньший возраст - $20673 \pm 100$ лет (ТА-63) (Лийва и др., 
1966). Такая резкая разница в полученных результатах объясняется, по-видимому, значительным «омоложением» пробы торфа, отобранной значительно позднее заложения колодца. Если считать возраст погребенной древесины сосны более правдоподобным, то органогенные отложения в Пээду следует отнести к средневалдайскому периоду потепления. Близкий к этому возраст имеют, вероятно, и подстилающие торфяной слой аллювиальные пески с линзами и кусками торфа. Залегающая на ложе погребенной долины серая морена вероятнее всего связана с предшествующей стадией наступания ледника в Южной Эстонии. Сохранение маломощного слоя более древней морены на ложе погребенной долины с последующим перерывом в осадконакоплении нам кажется неправдоподобным.

Таким образом, судя по имеющимся данным об абсолютном возрасте подморенных органогенных отложений в Карукюла и Пээду, во время средневалдайского потепления значительная часть территории Эстониі была свободна от материкового льда довольно длительное время. Но, к сожалению, точное сопоставление этих разрезов пока еще невозможно из-за отсутствия полной палинологической характеристики органогенных отложений Пээду. Кроме того, желательно повторить радиоуглеродные определения погребенных органогенных материалов из обоих местонахождений.

В покрывающей органогенные отложения 6,5-метровой моренной толще в Пээду выделяются по макролитологическим признакам две разновидности морены: красновато-бурая песчанисто-глинистая (мощностью 2 м) и буровато-серая до серой песчано-гравистая до глинистой (мощностью $4,5 \mathrm{M}$ ).

Для лучшей характеристики морен различного облика отобранные из трех моренных слоев образцы были подвергнуты минералогическому анализу.

Судя по данным анализа (таблица), эти морены, несмотря на близкий минералогический состав, отличаются по некоторым качественным и количественным показателям. Например, для красно-бурой морены (обр. 1) характерно присутствие небольшого количества зерен силлиманита и значительное содержание мусковита, а среди легких минералов - большего количества полевых шпатов. В верхней морене отсутствуют, как правило, зерна карбонатов, довольно часто встречающиеся в глинистой серой морене (обр. 2). Последняя бедна мусковитом и гидроокислами железа. Нижняя серая морена (обр. 3) отличается от других наличием небольшого количества пирита. В то же время по содержанию большинства аллотигенных тяжелых минералов описываемые морены существенно не отличаются друг от друга. Колебания в количествах отдельных минералов не выходят за пределы изменений, характерных для одновозрастных гляциальных отложений. Это указывает на елиную область сноса обломочного материала, а следовательно, и на незначительные изменения направления движения ледника в течение всего рассматриваемого времени на юго-востоке Эстонии.

Возраст нижней серой морены, залегающей в основании четвертичных отложений разреза и относимой к первой половине валдайского оледенения, а также верхней красно-бурой, относимой к лужской (хааньяской) стадии, не вызывает, на наш взгляд, сомнений. Остается открытым вопрос о возрасте серой глинистой морены, залегающей над органогенными отложениями Пээду. Возможно, что она верхневалдайскаs;, но во всяком случае древнее лужской стадии.

Из сказанного следует, что серые морены, нередко устанавливаемые в Южной Эстонии под красно-бурой мореной, не обязательно являются. 
Содержание минералов в образцах морен Пээду, \%

\begin{tabular}{|c|c|c|c|c|c|c|}
\hline \multirow[b]{2}{*}{ Минералы } & \multicolumn{2}{|c|}{ Обр. 1} & \multicolumn{2}{|c|}{ Обр. 2} & \multicolumn{2}{|c|}{ Обр. 3} \\
\hline & $\begin{array}{c}0,25- \\
0,10 \mathrm{MM}\end{array}$ & $\begin{array}{l}0,10- \\
0,05 \text { мM }\end{array}$ & $\begin{array}{c}0,25- \\
0,10 \mu \mu\end{array}$ & $\frac{0,10-}{0,05 \mu M}$ & $\begin{array}{c}0,25- \\
0,10 \text { мM }\end{array}$ & $\begin{array}{l}0,10- \\
0,05 \text { мM }\end{array}$ \\
\hline
\end{tabular}

Легкие минералы

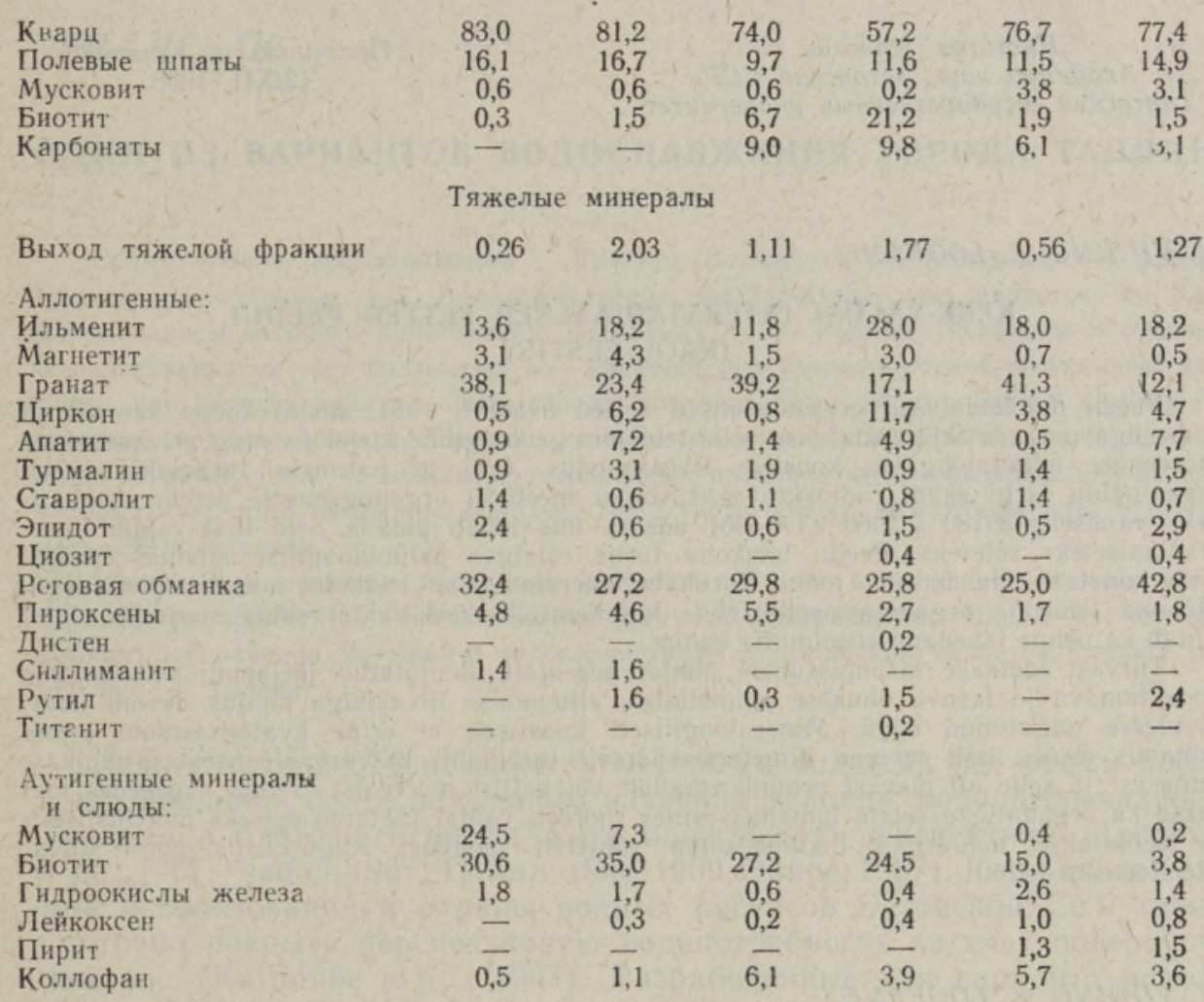

моренами среднеплейстоценового возраста. По нашему мнению, они скорее всего представляют собой отложения стадий валдайского оледенения. На разновозрастность фиолетово-серой морены Южной Эстонии указал и А. Раукас (1963), который по литологическому составу и характеру выделил среди них среднеплейстоценовые и стадиальные морены валдайского оледенения.

\section{ЛИТЕРАТ У РА}

Л и й в а А., Ильв ес Э., Пуннин нг Я.-М. 1966. Список радиоуглеродных датировок Института зоологии и ботаники Академии наук Эстонской ССР. Изв. АН ЭССР, Серия биол,, 14, № 1.

Ор в ику К. К., Пиррус Р. О. 1965. Межморенные органогенные отложения з Карукюла (Эстонская ССР). В сб.: Литология и стратиграфия четвертичных отложений Эстонии. Инст. геол. АН ЭССР. Таллин.

Пуннин г Я.-М., Ильвес Э., Л ий в а А. 1967а. Список радиоуглеродных датировок Института зоологии и ботаники Академии наук Эстонской ССР. Сообщение II. Изв. АН ЭССР, Биология, 16, № 4. 
Пунниннг Я.-М., Р аука с А. В., Серебрянны й Л. Р. 1967б. Геохронология последнего оледенения Русской равнины в свете новых радиоуглеродных датировок ископаемых озерно-болотных отложений Прибалтики. Материалы II симпозиума по истории озер Северо-Запада СССР (23-28 мая 1967). Минск.

$\mathrm{P}$ а у к а А. В. 1963. Литология разновозрастных морен Эстонской ССР. Тр. Ин-та геол. АН ЭССР, ХІІ.

С ер ебря нн ый Л. Р., Р а ука с А. В. 1966. Трансбалтийские коррелящии краевых ледниковых образований позднего плейстоцена. В сб.: Верхний плейстоцен. Стратиграфия и абсолютная геохронология. М.

Ннститут геологии

Академии наук Эстонской ССР

тартуский государственный университет
Поступила в редакцию $12 /$ XII 1968

\section{H. VIIDING, E. LOOKENE}

\section{KESK-VALDAI INTERSTADIAALSED SETTED PEEDUL}

(KAGU-EESTIS)

Peedu moreenialused organogeensed setted avastati 1964. aastal kaevu kaevamisel $7 \mathrm{~m}$ sügavusel. Artiklis esitatakse selle leiukoha geoloogiline kirjeldus ning erivanuseliste moreenide mineraloogilise koostise iseloomustus. $0,35 \mathrm{~m}$ paksuses turbakihis leitud männipuidu järgi saadi radioaktiivse süsiniku meetodil organogeensete setete absoluutseks vanuseks $39180+1960$. (TA-136) aastat, mis lubab pidada neid kesk-valdai interstadiaalseteks seteteks. Peedu leiukoha turba esialgse palünoloogilise analüüsi pōhjal võib konstateerida ühiseid jooni Karuküla interstadiaalse leiukoha suirakompleksidega. Mōlema leiukoha organogeensete setete kujunemisele kesk-valdai sama soojaaja vältel viitab ka nende lähedane absoluutne vanus.

Turvast loetakse lasumussuhete pōhjal aeg-ajalt üleujutatud jōelammi setteks, mis koos lamava ja lasuva ōhukese pôimkihilise alluviaalse liivakihiga kuhjus devoni liivakividesse uuristunud orgu. Mineraloogiliselt koostiselt ei erine kvaternaarsete setete lamamis esinev hall moreen nimetamisväärselt turbakihti katvast ülemisest pruunikaspunasest ja selle all olevast pruunikashallist vōi hallist moreenist. Sellele tuginedes loetakse ka orgaaniliste setete lamamis esinev moreen valdai jäätumisaegseks moodustiseks ja eeldatakse mandrijää liikumissuuna suhtelist püsivust Kagu-Eestis kogu ülempleistotseeni vältel.

\section{H. VIIDING, E. LOOKENE}

\section{MIDDLE VALDAI INTERSTADIAL DEPOSITS AT PEEDU} (SE ESTONIA)

The under-morainic organogenic deposits of Peedu were discovered in 1964 at the digging of a 7 -metre-deep well. The authors present a geological description of the deposit as well as the mineralogical composition of the different-aged tills. On the basis of the radioactive carbon method applied to the pine-wood remains found in a 0.35 metre-thick peat layer, the absolute age of the deposits was stated as $39,180 \pm 196 \mathrm{C}$ (TA-136) years, which allows to include them into the Middle Valdai interstade. According to preliminary palynological analysis of the peat of Peedu deposit, one may state features in common with the pollen complex of the interstadial deposit of Karuküla. The approximately equal absolute age of both the deposits points to those organogenic sediments being formed during the same warm period in the Middle Valdai.

According to bedding relations, the peat layer is considered to be a sediment of the river flat, overflowed from time to time; the peat layer, together with the underlying and overlying thin layer of obliquely laminated alluvial sand, accumulated in the valley formed in the Devonian sandstones. In its mineralogical composition, the grey till occurring in the Quaternary deposits does not differ to any considerable extent from the upper, reddish-brown one, overlying the peat layer, or from the underlying brownishred or grey till. On those grounds, the till occurring under the organic deposits is likewise considered to have been formed during the Valdai glaciation, and the direction of the movement of the continental ice in Southeast Estonia is assumed to have been relatively constant throughout the entire Upper Pleistocene. 